\title{
Carbonation of hybrid concrete with high blast furnace slag content and its impact on structural steel corrosion
}

\author{
D. E. Angulo-Ramirez ${ }^{\mathrm{a}}$, R. Mejía de Gutiérrez ${ }^{\mathrm{a}} \bowtie$, W. G. Valencia-Saavedra ${ }^{\mathrm{a}}$, \\ M. H. F. de Medeiros ${ }^{b}$, J. Hoppe-Filho ${ }^{c}$ \\ a. Grupo Materiales Compuestos, Universidad del Valle, (Cali, Colombia) \\ b. Federal University of Paraná, (Curitiba, Brazil) \\ c. Federal University of Western Bahia, (Bahía, Brazil) \\ \ruby.mejia@correounivalle.edu.co
}

Received 30 May 2018

Accepted 11 September 2018

Available on line 13 February 2019

\begin{abstract}
The aim of this research was to study the carbonation resistance of a blast furnace slag concrete (80\% GBFS/20\%OPC), with and without alkaline activation, and its influence on the corrosion of structural reinforcement. An OPC-based concrete produced under the same specifications was used as a reference material. To do this, the material was subjected to an accelerated carbonation process under controlled conditions ( $65 \%$ relative humidity, $1 \% \mathrm{CO}_{2}, 25^{\circ} \mathrm{C}$ ). The half-cell potential (Ecorr), linear polarization resistance (LPR) tests showed that both concretes based on GBFS led to depassivation of the reinforcing steel at approximately 99 days, which is the time required for full carbonation of the evaluated concretes.
\end{abstract}

KEYWORDS: Carbonation; Blast furnace slag; Blended Concrete; Alkali-activated concrete; Corrosion.

Citation/Citar como: Angulo-Ramirez, D.E.; Mejía de Gutiérrez, R.; Valencia-Saavedra, W.G.; de Medeiros, M.H. F.; Hoppe-Filho, J. (2019) Carbonation of hybrid concrete with high blast furnace slag content and its impact on structural steel corrosion. Mater. Construcc. 69 [333], e182 https://doi.org/10.3989/mc.2019.05418

RESUMEN: Carbonatación de un hormigón hibrido con alto contenido de escoria siderurgica de alto horno y su impacto en la corrosión del acero estructural. El objetivo de esta investigación fue estudiar la resistencia a la carbonatación de un hormigón a base de escoria granulada de alto horno ( $80 \%$ GBFS $/ 20 \% \mathrm{OPC}$ ), con y sin activación alcalina, y su influencia sobre la corrosión del acero estructural. Un hormigón basado en cemento portland producido con las mismas especificaciones fue usado como material de referencia. Para ello, el material fue sometido a un proceso de carbonatación acelerada bajo condiciones controladas (Humedad Relativa $65 \%, 1 \% \mathrm{CO}_{2}, 25{ }^{\circ} \mathrm{C}$ ). Los ensayos de potencial de media celda (Ecorr) y Resistencia a la polarización lineal (LPR) mostraron que los aceros estructurales aproximadamente a los 99 días alcanzan la despasivación en los hormigones basados en escoria, coincide este tiempo con el requerido para la completa carbonatación de los hormigones evaluados.

PALABRAS CLAVE: Carbonatación; Escoria granulada de alto horno; Hormigón Adicionado; Concreto activado alcalinamente; Corrosión

ORCID ID: D.E. Angulo-Ramírez (https://orcid.org/0000-0003-3506-3960); R. Mejía de Gutiérrez (https://orcid. org/0000-0002-5404-2738); W.G. Valencia-Saavedra (https://orcid.org/0000-0002-8918-2132); M.H.F. de Medeiros (https://orcid.org/0000-0003-3112-9715); J. Hoppe-Filho (https://orcid.org/0000-0002-9645-6808)

Copyright: (C) 2019 CSIC. This is an open-access article distributed under the terms of the Creative Commons Attribution 4.0 International (CC BY 4.0) License. 


\section{INTRODUCTION}

Most of the deterioration processes of reinforced concrete are related to carbonation and the presence of chlorides that generate corrosion processes in the reinforcing steel. Specifically, concrete carbonation is a natural phenomenon that consists of the diffusion and dissolution of $\mathrm{CO}_{2}$ in the pores of the concrete and the subsequent reaction or attack on portlandite $\left(\mathrm{Ca}(\mathrm{OH})_{2}\right)$ and tobermorite $(\mathrm{C}-\mathrm{S}-\mathrm{H})$, which generates calcium carbonate. This reaction causes a decreased alkalinity $(\mathrm{pH})$ in pore solution, which results in a loss of passivation in the steel, leading to the initiation and subsequent spread of corrosion (1-6).

To produce cements that are more environmentally friendly and durable and have better mechanical performance, studies of cements with added supplementary materials, such as fly ash, blast furnace slag, silica fumes, metakaolin (MK) and spent fluid catalytic cracking, have been conducted. However, it has been concluded that ordinary Portland cement (OPC) is more resistant to carbonation than cements with high amounts of these materials (4, 5, 7-10).

Alkali-activated, geopolymer and hybrid cements are other environmentally friendly cements that include between 70 and $100 \%$ blast furnace slag (GBFS) or fly ash as a cementitious material. These types of materials generally produce structures that are less permeable and have higher mechanical strengths; however, several studies (7, 11-15) have reported that Alkali-Activated Slag Concretes are more susceptible to carbonation, which they attribute to the small or non-existent amount of $\mathrm{Ca}(\mathrm{OH})_{2}$ available for neutralization by the $\mathrm{CO}_{2}$ diffused throughout the structure, and consequently, the attack on the C-S-H progresses faster and results in a greater loss of strength $(7,13)$.

Borges et al. (9) cured samples containing GBFS at $60^{\circ} \mathrm{C}$ and obtained denser structures (with more C-S-H gel) in addition to a decrease in the $\mathrm{CO}_{2}$ diffusion in the matrix, which increased the durability; however, the authors mentioned in their study that the presence of $\mathrm{CO}_{2}$ in alkali-activated mixtures also affects C-S-H by causing the degradation of gels by decalcification. Bernal et al. (16) confirmed the increased susceptibility of alkali-activated slag concretes with respect to concretes produced only with Portland cement; however, when comparing concretes containing more cementitious material $(300,400$ and $500 \mathrm{~kg} / \mathrm{m}^{3}$ ), they observed that this susceptibility decreases, which can be attributed to lower permeability or the direct relationship between the mechanical strength and the probability of carbonation, which has also been mentioned by other researchers (1). It should be noted that several factors could influence the degradation process in alkali-activated cements. Bernal et al. (17) assessed the impact of the activator solution modulus (Ms) and the incorporation of MK on the carbonation resistance of an alkali-activated blast furnace slag and found that susceptibility to carbonation is higher when the Ms is low. However, this behaviour is reversed when MK is added due to the formation of secondary silicoaluminate phases. By studying how the type of activator influences the carbonation resistance, Puertas et al. (15) found that the resistance to carbonation depends strongly on the type of activator used; therefore, by comparing sodium hydroxide with sodium silicate or waterglass $(\mathrm{Wg})$ they showed that the samples activated with $\mathrm{Wg}$ are more susceptible.

This study determined the carbonation resistance of a blast furnace slag concrete $(80 \%$ GBFS $/ 20 \%$ OPC) activated with a mixture of sodium silicate and sodium hydroxide and assesses its influence on the corrosion of the structural reinforcement. The results were compared with those obtained in the same blended concrete without alkaline activation. An OPC-based concrete produced under the same specifications was used as a reference material.

\section{MATERIALS AND METHODS}

This study used granulated blast furnace slag (GBFS) and a Portland cement (OPC) from Colombia (cement type GU according to ASTM C1157) as cementitious materials. Their chemical compositions and physical characteristics are shown in Table 1. It is important to note that the use of limestone added cement causes high loss on ignition (LOI). Diffractograms of the raw materials are shown in Figure 1. Three types of concrete are prepared, a concrete control based on OPC 100\%, a reference material $80 \% \mathrm{GBFS}+20 \% \mathrm{OPC}$ named $\mathrm{CE}$, and an alkali-activated concrete containing the same proportion of blast furnace slag named HB. A mixture of sodium hydroxide and sodium silicate was used as activator (Ms: $1 ; \% \mathrm{Na}_{2} \mathrm{O}: 5 \%$ with respect of GBFS). Table 2 shows the proportions of the materials used in this study.

Cylindrical concrete specimens $(76 \mathrm{~mm}$ in diameter and $152 \mathrm{~mm}$ in height) with and without

TABLE 1. Chemical compositions and particle size of the cementitious materials

\begin{tabular}{lcccccccc}
\hline $\mathbf{( \% )}$ & $\mathbf{S i O}_{\mathbf{2}}$ & $\mathbf{C a O}$ & $\mathbf{A l}_{2} \mathbf{O}_{3}$ & $\mathbf{F e}_{2} \mathbf{O}_{3}$ & $\mathbf{M g O}$ & $\mathbf{S O}_{3}$ & LOI & Particle size $(\boldsymbol{\mu m})$ \\
\hline OPC & 19.13 & 57.7 & 4.42 & 4.32 & 1.6 & 2.32 & 9.78 & 21.48 \\
GBFS & 31.99 & 46.86 & 14.54 & 1.12 & 1.05 & 0.82 & 1.8 & 21.38 \\
\hline
\end{tabular}



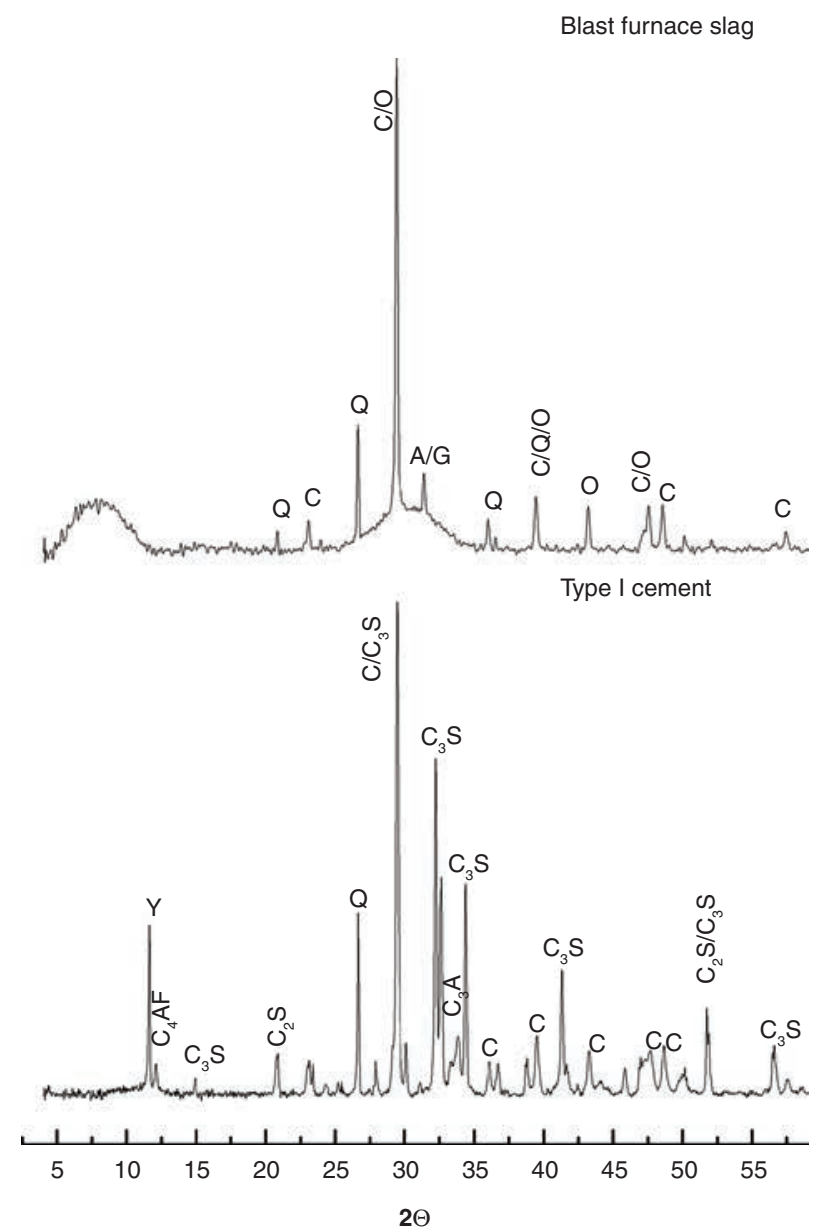

FiguRE 1. X-ray diffractograms of the raw materials used: Y: gypsum [PDF:00-021-0816], Q: quartz [PDF:00-033-1161], C: calcite [PDF:00-047-1743], A: akermanite [PDF:01-0870050], G: gehlenite [PDF:00-035-0755], O: olivine [PDF:01-0872039], $\mathrm{C}_{3} \mathrm{~S}$ [PDF:00-016-0406], $\mathrm{C}_{2} \mathrm{~S}$ [PDF:00-033-0302].

reinforcement were made; reinforcing steel $(6.35$ $\mathrm{mm}$ of diameter) was placed in the centre of a cylinder with an exposed area of $1000 \mathrm{~mm}^{2}$ inside the concrete (Figure 2). As shown in Table 2, the slump is held between 50 and $100 \mathrm{~mm}$ to promote medium or plastic consistency in the resulting concrete; this value is ideal for concrete placement by hand and for reinforced sections. The HB samples are cured for 28 days in a humidity chamber, and the reference (CE) and control (OPC) concrete samples are cured in water; subsequently, both are subjected to accelerated carbonation in a chamber under controlled conditions ( $65 \%$ relative humidity $\left.(\mathrm{RH}) ; 1 \% \mathrm{CO}_{2}, 25^{\circ} \mathrm{C}\right)$. Before being placed in the carbonation chamber, the specimens were preconditioned by drying for 6 hours at room temperature $\left(25^{\circ} \mathrm{C}, 80 \%\right.$ H.R. $)$, and a coat of impermeable paint was applied to the top and bottom surfaces of the cylinders. This treatment allows to lead the entrance of $\mathrm{CO}_{2}$. For the unreinforced concretes,
TABLE 2. Mixture design and properties of the fresh concretes

\begin{tabular}{lccc}
\hline Design and Properties & $\begin{array}{c}\text { REFERENCE } \\
\text { (CE) }\end{array}$ & $\begin{array}{c}\text { HYBRID } \\
\text { (HB) }\end{array}$ & OPC \\
\hline Cementitious material $\left(\mathrm{kg} / \mathrm{m}^{3}\right)$ & 400 & 400 & 400 \\
Blast furnace slag $\left(\mathrm{kg} / \mathrm{m}^{3}\right)$ & 320 & 295.31 & - \\
Portland cement $\left(\mathrm{kg} / \mathrm{m}^{3}\right)$ & 80 & 73.81 & - \\
Sodium silicate $\left(\mathrm{kg} / \mathrm{m}^{3}\right)$ & - & 44.26 & - \\
Sodium hydroxide $\left(\mathrm{kg} / \mathrm{m}^{3}\right)$ & - & 12.19 & - \\
Fine aggregate: sand $\left(\mathrm{kg} / \mathrm{m}^{3}\right)$ & 972.7 & 989.9 & 972.7 \\
Coarse aggregate: crushed & 704.4 & 716.9 & 704.4 \\
gravel $\left(\mathrm{kg} / \mathrm{m}^{3}\right)$ & & & \\
Water $\left(\mathrm{kg} / \mathrm{m}^{3}\right)$ & 192 & 180 & 192 \\
Liquid $/ \mathrm{solid}$ ratio & 0.48 & 0.45 & 0.48 \\
Slump $(\mathrm{mm})$ & \multicolumn{4}{c}{70} \\
\end{tabular}

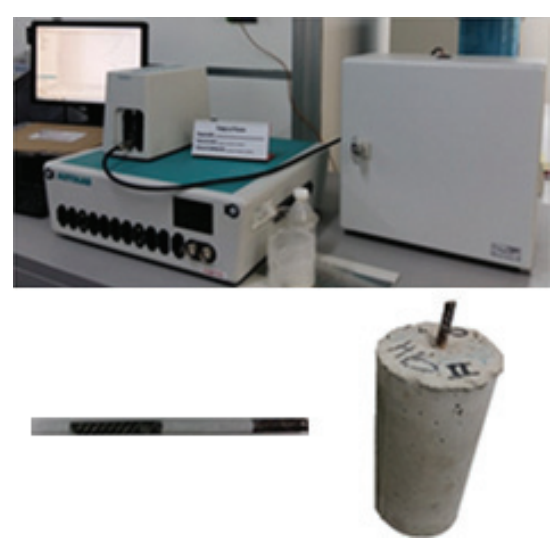

Figure 2. Setup for the electrochemical measurements of reinforced concretes exposed to carbonation.

the carbonation front is located by making cross cuts every 8 days for evaluation with phenolphthalein. For the steel reinforced concretes, the half-cell potential (Ecorr) according to ASTM C876 standard (18) and the linear polarization resistance (LPR) following the procedure of the ASTM G59 (19) standard were measured every 30 days. These electrochemical tests were performed using an Autolab PGSTAT128N Potenciostat/Galvanostat instrument (Figure 2). $\mathrm{Ag} / \mathrm{AgCl}$ was used as the reference electrode and stainless steel as counterelectrode. The calculation of the corrosion current density was carried out by applying the SternGeary equation. These electrochemical measurements were also carried out on the same concretes immersed in water, environment used as a comparison to the accelerated carbonation environment.

Pastes with the same proportions of cementitious material and activator were prepared to monitor the progress of the hydration reactions using X-ray diffraction. 


\section{RESULTS AND DISCUSSION}

\subsection{Hydration process and physical-mechanical properties}

Figure 3 shows diffractograms of the $\mathrm{HB}$ and CE (OPC/GBFS $20 \% / 80 \%$ ) pastes after 28 days of curing. The diffractograms showed the presence of some crystalline components of the raw materials (Figure 1) and of the reaction products. The presence of quartz, calcite, aragonite and C-S-H can be observed in both types of concrete, and in particular, hydrated gehlenite $\left(\mathrm{C}_{2} \mathrm{ASH}_{8} / \mathrm{C}_{4} \mathrm{AH}_{13}\right)$ is found in the hybrid samples; this is a hydration product characteristic of slags that are alkali activated using sodium silicate and sodium hydroxide (20) and is associated with the absence of portlandite in these samples (21). Some researchers have noted that due to the reduced amounts of OPC in the mixtures $(20 \%)$, it is possible for portlandite $\left(\mathrm{Ca}(\mathrm{OH})_{2}\right)$ not to be found $(22,23)$; conversely, other studies have shown that it is possible for a small amount to participate in the reaction with the GBFS or the silicate present as an activator to generate more $\mathrm{C}-\mathrm{S}-\mathrm{H}$ $(24,25)$.

Table 3 shows the physical-mechanical properties of the $\mathrm{CE}$ and $\mathrm{HB}$ samples evaluated and compares them to those of a $100 \%$ OPC concrete. It is observed that the compressive strength of the CE after 28 days of curing is approximately $50 \%$ less than that of the $\mathrm{HB}$ and $100 \%$ OPC concretes. This behaviour is in agreement with the results of different studies that have shown that the strengths of concretes with high
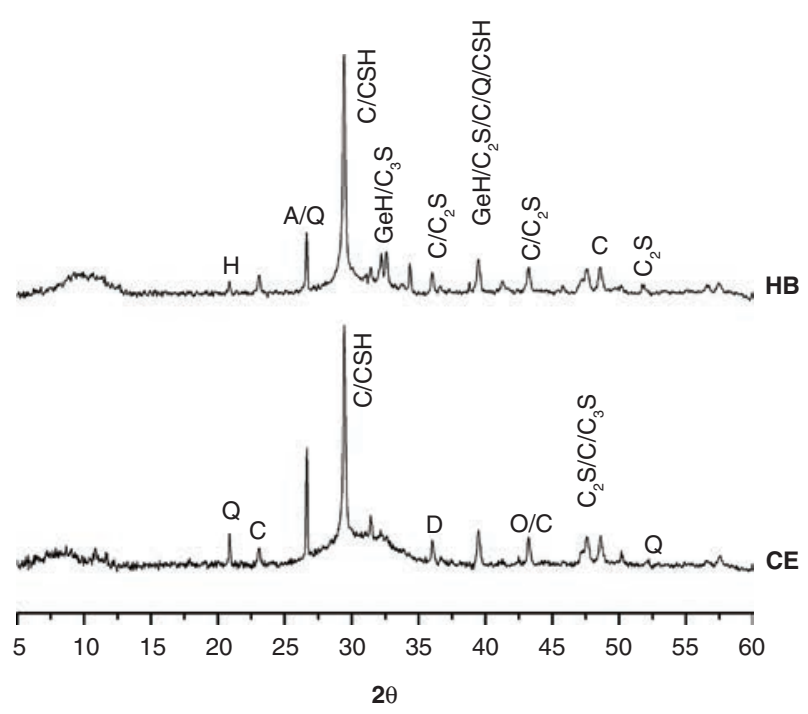

Figure 3. Diffractograms of the hybrid (HB) and reference (CE) cement pastes. Hydration products monitored after 28 days of curing: A: aragonite; C: calcite [PDF:00-047-1743]; $\mathrm{H}$ : hydrotalcite [PDF:01-089-0460]; GeH: hydrated gehlenite $\left(\mathrm{C}_{2} \mathrm{ASH}_{8} / \mathrm{C}_{4} \mathrm{AH}_{13}\right)$ [PDF:01-089-1580]; Q: quartz [PDF:00-0331161]; D: diopside; O: olivine [PDF:01-087-2039], $\mathrm{C}_{3} \mathrm{~S}$ [PDF:00016-0406], C 2 S [PDF:00-033-0302], C-S-H [PDF:01-074-2596]
TABLE 3. Physical-mechanical properties prior to carbonation testing ( 28 days of curing)

\begin{tabular}{|c|c|c|c|}
\hline Properties & $\mathbf{C E}$ & HB & $\begin{array}{l}100 \% \\
\text { OPC }\end{array}$ \\
\hline Compressive strength (MPa) & 16.30 & 34.04 & 30.93 \\
\hline \multicolumn{4}{|l|}{ Water Absorption } \\
\hline$\%$ Permeable pores & 17.25 & 14.41 & 15.98 \\
\hline$\%$ Total absorption & 7.05 & 6.34 & 7.17 \\
\hline \multicolumn{4}{|l|}{ Capillary suction } \\
\hline Absorption coefficient $\left(\mathrm{K}, \mathrm{kg} / \mathrm{m}^{2} \cdot \mathrm{seg}^{1 / 2}\right)$ & 0.02 & 0.01 & 0.03 \\
\hline Effective porosity $(\%)$ & 9.65 & 6.99 & 12.70 \\
\hline $\begin{array}{l}\text { Resistance to water penetration } \\
\left(\mathrm{m}^{*} 10^{7}, \mathrm{~s} / \mathrm{m}^{2}\right)\end{array}$ & 2.63 & 2.51 & 1.90 \\
\hline
\end{tabular}

contents $(30 \%-90 \%)$ of blast furnace slag replacing Portland cement after 28 days of curing are lower than those of the $100 \%$ OPC control samples, which is due to the relatively low reaction rate of the slag (26-35). Therefore, it is concluded that gradually increasing the amount of slag in the concrete causes a reduction on the compressive strength at early ages. Regarding absorption and porosity, note that the differences in the total absorption and the porosity are directly related to the reported strength. However, the capillary absorption coefficient $(\mathrm{K})$, resistance to water penetration $(\mathrm{m})$ and effective porosity indicate that both the $\mathrm{CE}$ and the alkaliactivated HB are less permeable than the $100 \%$ OPC concrete; this is attributable to greater refinement in the pore structure, behaviour that coincides with the research carried out by Rodríguez et al. (36), these results indicate the presence of a more dense and resistant structure.

\subsection{Carbonation front}

Figure 4 shows the progress of the carbonation front of the HB and CE samples, which is compared with the behaviour of a $100 \%$ OPC concrete produced with the same mixture proportions. The samples were subjected to accelerated carbonation conditions $\left(65 \% \mathrm{RH}, 1 \% \mathrm{CO}_{2}\right.$ and $\left.25^{\circ} \mathrm{C}\right)$ after 28 days of curing.

In general, all the concretes show gradual carbonation (Figure 5 through Figure 7); however, the $\mathrm{HB}$ and $\mathrm{CE}$ samples became completely carbonated in a shorter period (99 days) compared to the $100 \%$ OPC concrete, which showed a carbonation depth of $13 \mathrm{~mm}$ at same age of exposure. Therefore, the high susceptibility to accelerated carbonation of the HB and CE concretes has been demonstrated, and it should be noted that although the HB sample generally has a greater compressive strength and lower permeability than the 100\% OPC and $\mathrm{CE}$ concretes, its susceptibility to carbonation is higher. 


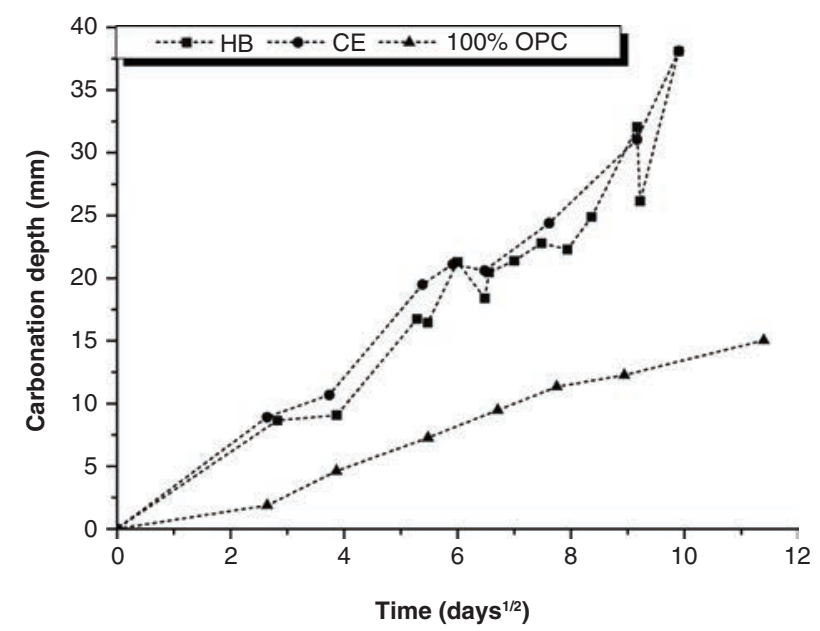

FIgURE 4. Carbonation depth versus exposure time.

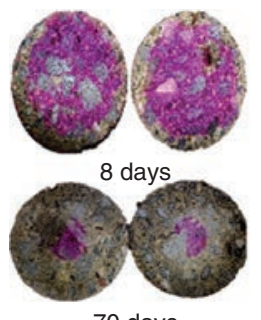

70 days

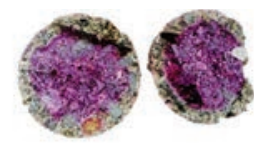

15 days

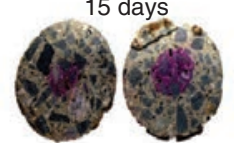

88 days

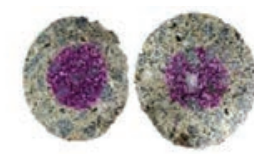

41 days

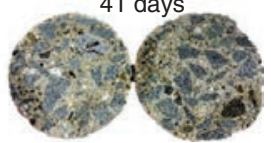

99 days
FIGURE 5. Advancement of the carbonation front in alkali-activated blended concrete (HB).

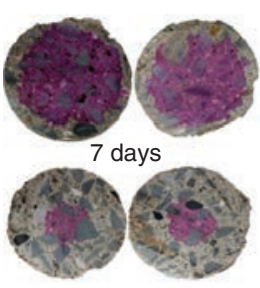

58 days

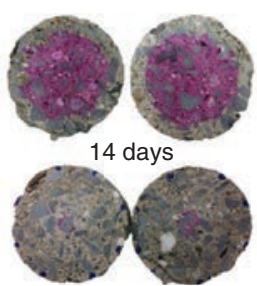

84 days

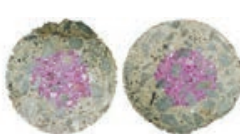

42 days

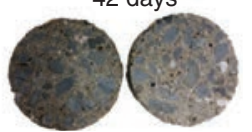

99 days
FIGURE 6. Advancement of the carbonation front in blended concrete without alkaline activation (CE).

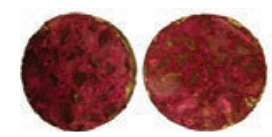

0 days

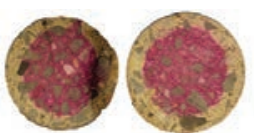

60 days

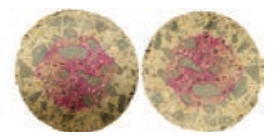

104 days
Figure 7. Advancement of the carbonation front in the $100 \%$ OPC reference concrete.

Some authors $(7,9,37,38)$ have suggested that the greater susceptibility of the carbonation process is proportional to the amount of blast furnace slag and independent of the decreased porosity caused by the added material, especially in concretes containing $70 \%$ or more of GBFS, although their compressive
TABLE 4. Compressive strength before and after the concretes were placed in the accelerated carbonation chamber

\begin{tabular}{lccc}
\hline Concrete (MPa) & 28 days & 90 days & 99 days in $\mathbf{C O}_{\mathbf{2}}$ \\
\hline $\mathrm{CE}$ & 16.29 & 20.72 & 3.35 \\
$\mathrm{HB}$ & 34.04 & 36.02 & 3.60 \\
$100 \%$ OPC & 30.93 & 40.24 & 49.96 \\
\hline
\end{tabular}

strength remains high. This greater susceptibility is also associated with the decalcification of the C-S-H gel $(11,15,39)$, which affects the mechanical properties, as shown in Table 4, in which the mechanical strengths of the concretes are compared before and after the samples are subjected to the accelerated carbonation process; it can be seen that after exposure to $\mathrm{CO}_{2}$ for 99 days, compared to those samples cured in the absence of $\mathrm{CO}_{2}$, the compressive strength of these samples decreases drastically. The residual strength of $\mathrm{CE}$ and $\mathrm{HB}$, after 99 days of accelerated exposure to $\mathrm{CO} 2$, was similar $(3.35$ and $3.60 \mathrm{MPa}$, respectively). However, it is to be noted that due to the higher initial resistance of HB (34.04 MPa), which is approximately two times higher than the corresponding from $\mathrm{CE}$ to 28 days of normal curing, the loss of compressive strength calculated was superior $(89 \%)$. On the contrary, in the case of OPC concrete, the compressive strength to the same age of exposure presented an increase, which is related to the lower carbonation depth (Figure 4). Similar behaviours have been found by Backharev et al., Bernal et al. (17, 40,41 , who noted that concretes containing alkaliactivated GBFS exhibited higher rates of carbonation even though they are more alkaline than $100 \%$ OPC concretes and blended concretes with pozzolan. The higher alkalinity of alkali-activated concretes is due to the activators, in this case, to a mixture of sodium silicate and sodium hydroxide (with a $\mathrm{pH}$ of greater than 13.5), whereas the $\mathrm{pH}$ of the OPC paste is between 12.6 and $13.5(11,42)$. Some authors $(16$, $37,43,44)$ have noted that the adverse behaviour of the alkaline-activated concretes towards carbonation can be controlled and reduced by using a larger proportion of cementitious material, a lower water/ cementitious material ratio and a higher Ms.

Due to the large number of factors that affect the results, it is difficult to establish a correlation between the exposure times under accelerated and natural conditions. Several authors (45-48) have suggested that there is a relationship between natural exposure $\left(\mathrm{K}_{\mathrm{N}}\right)$ and exposure to accelerated conditions (Kc) that can be expressed using [1]

$$
\frac{K_{C}}{K_{N}}=\sqrt{\frac{C}{N}},
$$

where $\mathrm{C}$ represents the $\mathrm{CO}_{2}$ concentration of the accelerated environment and $\mathrm{N}$ represents the $\mathrm{CO}_{2}$ 
concentration of the natural environment; for the purpose of analysing this condition, an environment with a $\mathrm{CO}_{2}$ concentration of $0.1 \%$ or $[\mathrm{N}=0.1]$ was assumed, and the values of $K^{N}$ were calculated (Table 5). In this case, $\mathrm{C}$ corresponds to the value used in the accelerated environment $\left(1 \% \mathrm{CO}_{2}\right)$ and $K^{C}$ to the value obtained during the test. It should be noted that these expressions have been developed for Portland cement concrete.

Using the values of $K^{N}$ found for each of the concretes evaluated, the time required for complete carbonation $\left(t^{C}\right)$ can be estimated in an environment containing $0.1 \% \mathrm{CO}_{2}$, as shown in Table 5. Note that the time required for the $100 \%$ OPC concrete is greater than 50 years, which is the estimated time required for a medium-strength Portland cement concrete, whereas the $\mathrm{HB}$ and $\mathrm{CE}$ concretes require only 10 years; this demonstrates the increased susceptibility to carbonation of Portland concretes with high percentages of GBFS and hybrid alkali-activated concretes based on $80 \%$ GBFS in urban and industrial environments containing $\mathrm{CO}_{2}$ emissions at concentrations of $0.1 \%$. However, as explained by Duffó et al. (49), for a good concrete, the values of

TABLE 5. Carbonation coefficients of the concretes evaluated $\left(\mathrm{mm} /\right.$ day $\left.^{1 / 2}\right)[\mathrm{N}=0.1]$

\begin{tabular}{lcc}
\hline Concrete & $\mathbf{K}_{\mathbf{N}}$ & $\mathbf{t}_{\mathbf{c}}$ (Years) \\
\hline $\mathrm{CE}$ & 0.6629 & 9.05 \\
$\mathrm{HB}$ & 0.6212 & 10.31 \\
$100 \%$ OPC & 0.2607 & 58.52 \\
\hline
\end{tabular}

$\mathrm{K}$ are between 0.25 and 1; based on this and as Table 5 shows, the HB and the concrete CE (80\% slag- $20 \%$ cement) can be considered also good, as is the $100 \%$ OPC concrete subjected to natural carbonation.

\subsection{Corrosion susceptibility of the carbonated material}

Figure 8 shows the half-cell potential (Ecorr) over time for the steel embedded in the $\mathrm{HB}$ and $\mathrm{CE}$ concretes in an accelerated carbonation environment $\left(65 \% \mathrm{RH}, 1 \% \mathrm{CO}_{2}\right.$ and $\left.25^{\circ} \mathrm{C}\right)$. In general, both concretes exhibit similar behaviour. In accordance with ASTM C876 [18] and (50), during the first 95 days of exposure, Ecorr is in a zone in which corrosion may or may not occur (between -0.10 and $-0.25 \mathrm{~V}$ vs. $\mathrm{Ag} / \mathrm{AgCl}$ ). After 120 days of exposure, the values of Ecorr for the concretes decrease drastically until they reach the level at which the probability of corrosion is $90 \%$. These results coincide with those obtained in the carbonation front test, which showed complete carbonation of the concretes at the same exposure age (Figures 4 through Figure 7). After this age, Ecorr values of both concretes, hybrid and reference, show a variable behaviour, with potential values between -0.25 and $-0.60 \mathrm{~V}$ vs. $\mathrm{Ag} / \mathrm{AgCl}$ until approximately 700 days in an accelerated carbonation chamber, thus remaining in the zone of $90 \%$ probability that corrosion will occur. It is observed, from the 425 days of exposure in samples of reinforced hybrid concrete submerged in water, as well as in those exposed to accelerated carbonation, a similar behaviour regarding the corrosion potential.

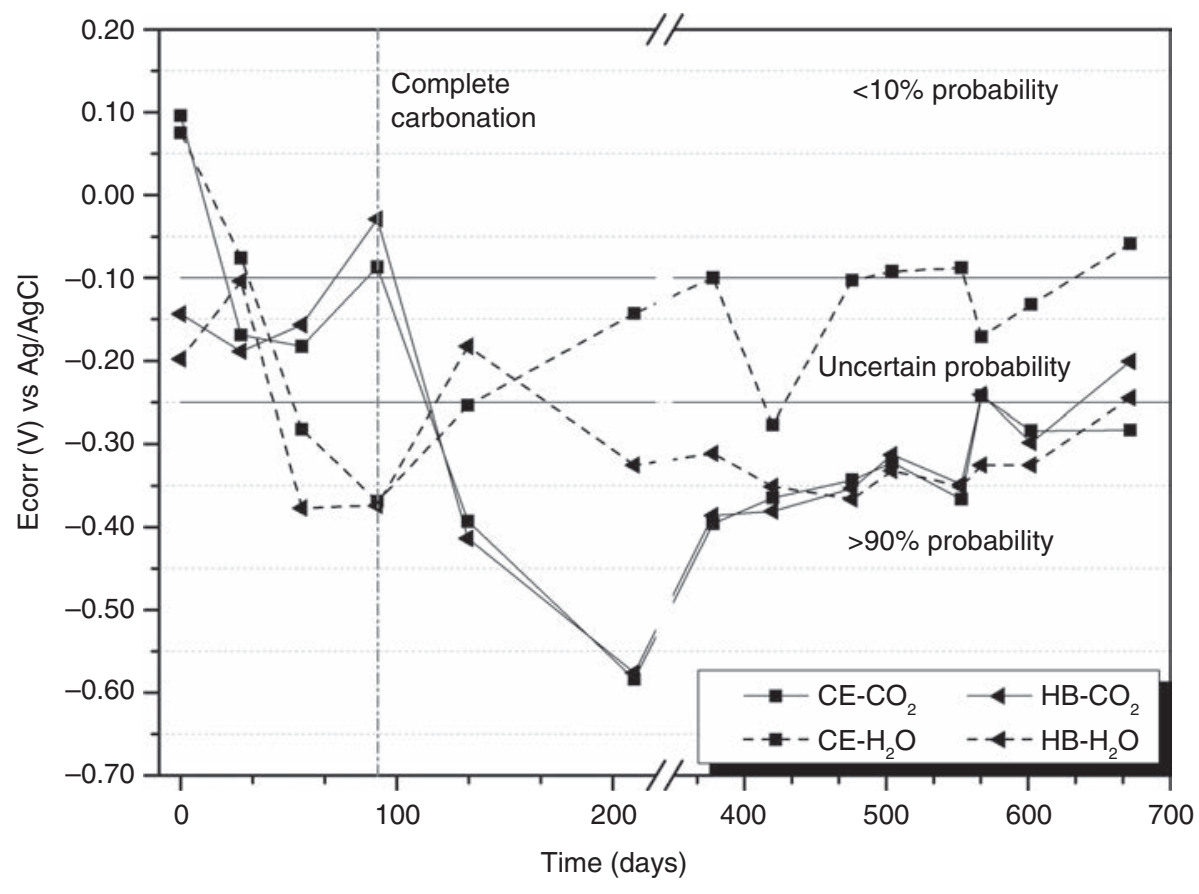

Figure 8. Comparison of the corrosion potentials of the concretes evaluated. 
Figure 9 shows the values of the corrosion current density (icorr) of the steel embedded in the concretes evaluated, calculated from measurements of LPR using the Stern-Geary equation. All the concretes showed high icorr above $2 \mu \mathrm{A} / \mathrm{cm}^{2}$. These results are strongly correlated with those obtained in the corrosion potential test (Figure 8), in which both concretes are likely to become corroded. The steels extracted from the different concretes to confirm that the corrosion has occurred (Figure 10). The results of the electrochemical tests are associated with the results of Aperador et al. $(51,52)$. These authors evaluated alkali-activated concretes containing GBFS $(100 \%)$ and attributed the high carbonation rate, among other factors, to micro-cracks produced by the contraction of these materials during the drying process. These micro-cracks facilitate the entry of $\mathrm{CO}_{2}$ into the structure; this has also been explained by other researchers $(14,39)$. Additionally, Bernal et al. (53) noted that the advancement of the carbonation process contributes to increases in the porosity, and consequently, this phenomenon contributes to the acceleration of the corrosion process. Alcaide et al. (54) studied the effect of carbon fibre on alkali-activated slag mortars reinforcing steel corrosion and showed that the maximum corrosion density reached in the carbonation process is $5.7 \mu \mathrm{A} / \mathrm{cm}^{2}$, after around 50 days this value flattened to $2.5 \mu \mathrm{A} / \mathrm{cm}^{2}$, this is because to the interaction between the $\mathrm{CO}_{2}$ and $\mathrm{C}-\mathrm{S}-\mathrm{H}$ gel and

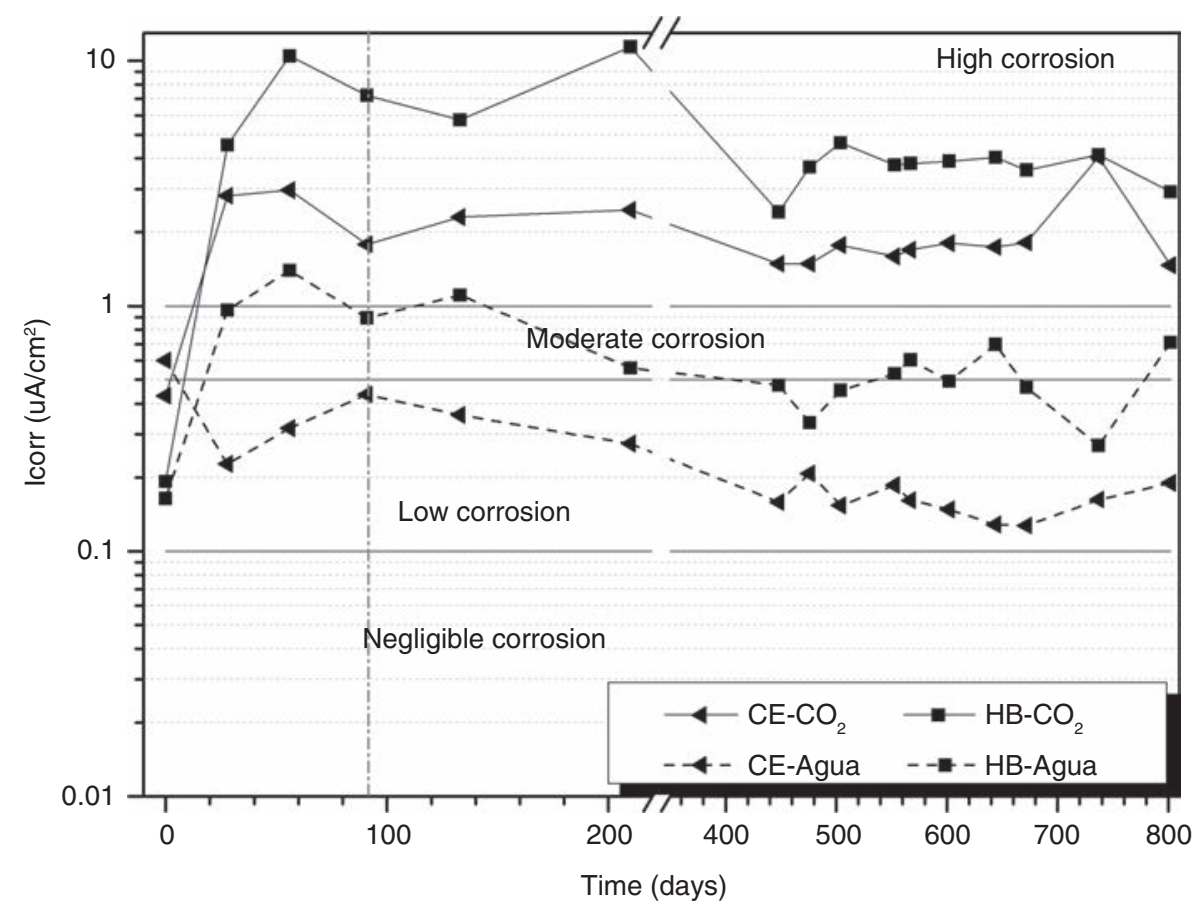

FIGURE 9. Corrosion current density of the concretes evaluated.
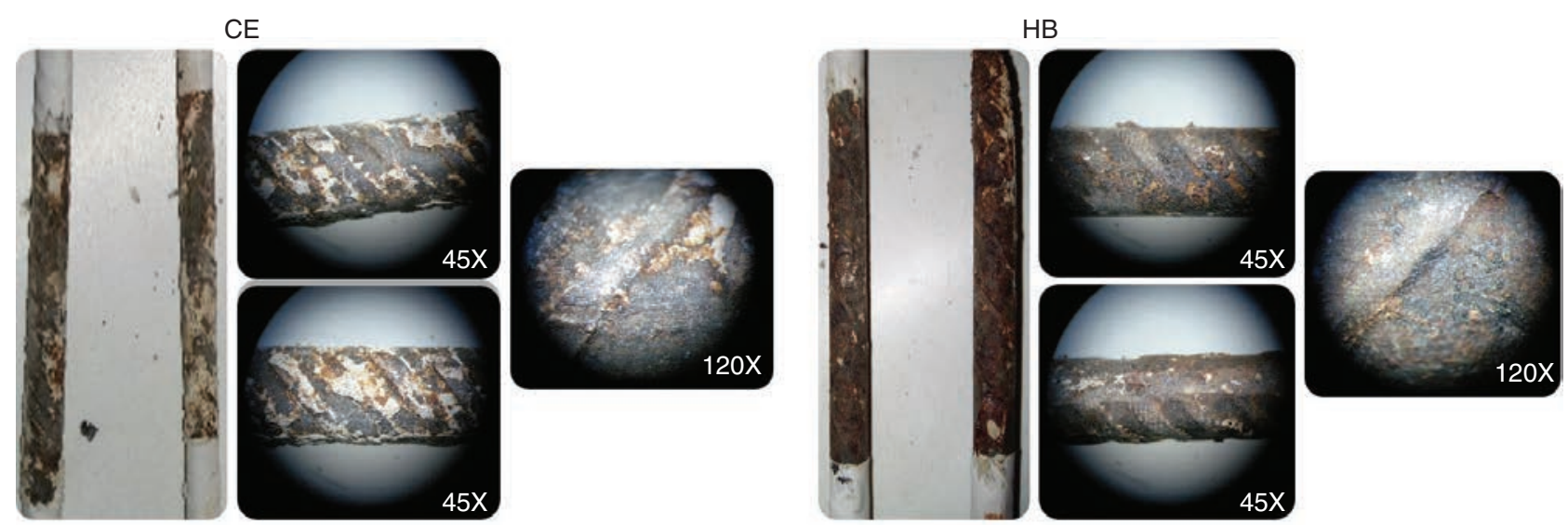

FIGURE 10. Steels extracted from CE and HB concretes exposed to accelerated carbonation. 
additionally to the presence of carbonaceous materials which modify the reaction kinetics. However, it is possible to increase the useful life of these alkaliactivated reinforced concretes and to decrease their susceptibility to carbonation by appropriately controlling the design of the concrete, especially the proportion of cementitious material and the type and proportion of the alkaline activator (55-57).

\section{CONCLUSIONS}

This study evaluated the susceptibility to carbonation of a blast furnace slag concrete $(80 \%$ GBFS $/ 20 \% \mathrm{OPC}$ ), with and without alkaline activation, named $\mathrm{HB}$ and $\mathrm{CE}$ respectively. The concretes were exposed to accelerated carbonation conditions $\left(65 \% \mathrm{RH}, 1 \% \mathrm{CO}_{2}\right.$ and $\left.25^{\circ} \mathrm{C}\right)$ and the decrease in compressive strength and the carbonation front were measured. A concrete based on OPC was used as reference. The susceptibility of these concretes to corrosion was also assessed using the corrosion potential and the linear polarization technique. From the results obtained, the following is concluded:

- HB and CE concretes showed a greater susceptibility to accelerated carbonation than Portland cement concrete.

- Under accelerated carbonation conditions, CE (80\%GBFS $/ 20 \% \mathrm{OPC}$ ) lost up to $79 \%$ of its initial strength, and HB lost $89 \%$ of its initial strength at 99 days of exposition. It is to be pointed out that the initial compressive strength of HB is twice as high as that of $\mathrm{CE}$, but the strength after the exposition were similar.

- Complete carbonation $(100 \%)$ of both concretes (CE y HB) was observed at 99 days of $\mathrm{CO}_{2}$ exposure. However, the OPC concrete barely reached $35,3 \%$ of carbonation depth at same age.

- When the actual time for complete carbonation of the evaluated concretes under aggressive environmental conditions $\left(0.1 \% \mathrm{CO}_{2}\right)$ was estimated, it was found that the blended Portland concrete $(80 \% \mathrm{GBFS} / 20 \% \mathrm{OPC})$ required 9 years, the $\mathrm{HB}$ (alkali-activated concrete $80 \% \mathrm{GBFS} / 20 \% \mathrm{OPC}$ ) required 10 years and the Portland cement concrete required approximately 58 years.

- The corrosive process of the steel reinforcement in the concrete with the addition of GBFS $80 \%$, $\mathrm{CE}$ and $\mathrm{HB}$ began after 99 days of exposure to an accelerated carbonation environment, and corrosion current density greater than $1 \mu \mathrm{A} / \mathrm{cm}^{2}$ could be observed.

\section{ACKNOWLEDGEMENTS}

This study was funded by the Colombian Institute for the Development of Science, Technology, and Innovation COLCIENCIAS (Project Hybricement
(Contract $\mathrm{N}^{\circ}$ 0638-2013). The authors also thank the University of Valle (Cali, Colombia), and the Centre of Excellence of Novel Materials (CENM).

\section{REFERENCES}

1. Fernández Bertos, M.; Simons, S.J.R.; Hills, C.D.; Carey, P.J. (2004) A Review of Accelerated Carbonation Technology in the Treatment of Cement-Based Materials and Sequestration of $\mathrm{CO}_{2}$. J. Hazard. Mater. 112 [3], 193-205. https://doi.org/10.1016/j.jhazmat.2004. 04.019 .

2. Galán García, I.; Andrade Perdrix, C.; Prieto Rábade, M.; Mora Peris, P.; López Agüí, J.C.; San Juan Barbudo, M.Á. (2010) Estudio Del Efecto Sumidero de CO2 de los Materiales de Base Cemento. Cemento y Hormigón, 939, 70-83.

3. Lim, M.; Han, G.-C.; Ahn, J.-W.; You, K.-S. (2010) Environmental Remediation and Conversion of Carbon Dioxide $\left(\mathrm{CO}_{2}\right)$ into Useful Green Products by Accelerated Carbonation Technology. Int. J. Environ. Res. and Public Health 7 [1], 203-228. https://doi.org/10.3390/ ijerph7010203.

4. Marques, P.F.; Chastre, C.; Nunes, Â. (2013) Carbonation Service Life Modelling of RC Structures for Concrete with Portland and Blended Cements. Cem. Concr. Compos. 37, 171-184. https://doi.org/10.1016/j.cemconcomp.2012. 10.007 .

5. Zornoza, E.; Payá, J.; Monzó, J.; Borrachero, M. V.; Garcés, P (2009) The Carbonation of OPC Mortars Partially Substituted with Spent Fluid Catalytic Catalyst (FC3R) and Its Influence on Their Mechanical Properties. Constr. Build. Mater. 23 [3], 1323-1328. https://doi.org/10.1016/j. conbuildmat.2008.07.024

6. Yuanhua, L.; Dajiang, Z.; Dezhi, Z.,; Yuanguang, Y.; Taihe, S.; Kuanhai, D.; Chengqiang, R.; Deping, Z.; Feng, W. (2013) Experimental Studies on Corrosion of Cement in $\mathrm{CO}_{2}$ Injection Wells under Supercritical Conditions. Corros. Sci. 74, 13-21. https://doi.org/10.1016/j.corsci. 2013.03.018.

7. Gruyaert, E.; Van den Heede, P.; De Belie, N. (2013) Carbonation of Slag Concrete: Effect of the Cement Replacement Level and Curing on the Carbonation Coefficient - Effect of Carbonation on the Pore Structure. Cem. Concr. Compos. 35 [1], 39-48. https://doi. org/10.1016/j.cemconcomp.2012.08.024.

8. Khalil, E.A.B.; Anwar, M. (2015) Carbonation of Ternary Cementitious Concrete Systems Containing Fly Ash and Silica Fume. Water Sci. 29 [1], 36-44. https://doi. org/10.1016/j.wsj.2014.12.001.

9. Borges, P.H.R.R.; Costa, J.O.; Milestone, N.B.; Lynsdale, C.J.; Streatfield, R.E. (2010) Carbonation of $\mathrm{CH}$ and $\mathrm{C}-\mathrm{S}-\mathrm{H}$ in Composite Cement Pastes Containing High Amounts of BFS. Cem. Concr. Res. 40 [2], 284-292. https:// doi.org/10.1016/j.cemconres.2009.10.020.

10. Osborne, G.J. (1999) Durability of Portland Blast-Furnace Slag Cement Concrete. Cem. Concr. Compos. 21 [1], 11-21. https://doi.org/10.1016/S0958-9465(98)00032-8.

11. Bakharev, T.; Sanjayan, J.G.; Cheng, Y.B. (2001) Resistance of Alkali-Activated Slag Concrete to Carbonation. Cem. Concr. Res. 31 [9], 1277-1283. https://doi.org/10.1016/ S0008-8846(01)00574-9

12. Bilim, C.; Atiș, C.D.; Ati, C.D.; Atiş, C.D. (2012) Alkali Activation of Mortars Containing Different Replacement Levels of Ground Granulated Blast Furnace Slag. Constr. Build. Mater. 28 [1], 708-712. https://doi.org/10.1016/j. conbuildmat.2011.10.018.

13. Law, D.W.; Adam, A.A.; Molyneaux, T.K.; Patnaikuni, I. (2012) Durability Assessment of Alkali Activated Slag (AAS) Concrete. Mater. Struct. 45 [9], 1425-1437. https:// doi.org/10.1617/s11527-012-9842-1.

14. Bilim, C.; Karahan, O.; Atiş, C.D.; İlkentapar, S. (2015) Effects of Chemical Admixtures and Curing Conditions on Some Properties of Alkali-Activated Cementless Slag 
Mixtures. KSCE J. Civ. Eng. 19 [3], 733-741. https://doi. org/10.1007/s12205-015-0629-0.

15. Puertas, F.; Palacios, M.; Vázquez, T. (2006) Carbonation Process of Alkali-Activated Slag Mortars. J. Mater. Sci. 41 [10], 3071-3082. https://doi.org/10.1007/ s10853-005-1821-2.

16. Bernal, S.A.; Mejía de Gutiérrez, R.; Pedraza, A.L.; Provis, J.L.; Rodriguez, E.D; Delvasto, S. (2011) Effect of Binder Content on the Performance of Alkali-Activated Slag Concretes. Cem. Concr. Res. 41 [1], 1-8. https://doi. org/10.1016/j.cemconres.2010.08.017.

17. Bernal, S.A.; Mejía de Gutierrez, R.; Provis, J.L.; Rose, V. (2010) Effect of Silicate Modulus and Metakaolin Incorporation on the Carbonation of Alkali SilicateActivated Slags. Cem. Concr. Res. 40 [6], 898-907. https:// doi.org/10.1016/j.cemconres.2010.02.003.

18. ASTM C876-15. (2015) Standard Test Method for Corrosion Potentials of Uncoated Reinforcing Steel in Concrete. West Conshohocken, PA. https://doi. org/10.1520/C $0876-15$

19. ASTM G59-97. (2014) Standard Test Method for Conducting Potentiodynamic Polarization Resistance Measurements. West Conshohocken, PA. https://doi. org/10.1520/G0059-97R14.

20. Shi, C.; Krivenko, P. V.; Roy, D.M. (2006) Alkali-Activated Cements and Concretes. Taylor \& Francis, Abingdon, UK. https://doi.org/10.4324/9780203390672.

21. Torres, J.; Mejía de Gutiérrez, R.; Castelló, R.; Vizcayno, C. (2008) Proceso de Hidratación de Pastas de OPC Adicionadas Con Caolín Tratado Térmicamente. Rev. Fac. Ing. Univ. Antioquia 43, 77-85.

22. Elahi, A.; Khan, Q.U.Z.; Barbhuiya, S.A.,; Basheer, P.A.M.; Russell, M.I. (2012) Hydration Characteristics of Cement Paste Containing Supplementary Cementitious Materials. Arab. J. Sci. Eng. 37 [3], 535-544. https://doi. org/10.1007/s13369-012-0193-6.

23. Lizarazo-Marriaga, J.; Claisse, P.; Ganjian, E. (2011) Effect of Steel Slag and Portland Cement in the Rate of Hydration and Strength of Blast Furnace Slag Pastes. J. Mater. Civ. Eng. 23 [2], 153-160. https://doi.org/10.1061/ (ASCE)MT.1943-5533.0000149

24. Acevedo-Martinez, E.; Gomez-Zamorano, L.Y.; EscalanteGarcia, J.I. (2012) Portland Cement-Blast Furnace Slag Mortars Activated Using Waterglass: - Part 1: Effect of Slag Replacement and Alkali Concentration. Constr. Build. Mater. 37, 462-469. https://doi.org/10.1016/j. conbuildmat.2012.07.041.

25. Escalante-Garcia, J.I.; Castro-Borges, P.; Gorokhovsky, A.; Rodriguez-Varela, F.J. (2014) Portland CementBlast Furnace Slag Mortars Activated Using Waterglass: Effect of Temperature and Alkali Concentration. Constr. Build. Mater. 66, 323-328. https://doi.org/10.1016/j. conbuildmat.2014.04.120.

26. Wang, Q.; Yan, P.; Mi, G. (2012) Effect of Blended Steel Slag-GBFS Mineral Admixture on Hydration and Strength of Cement. Constr. Build. Mater. 35, 8-14. https:// doi.org/10.1016/j.conbuildmat.2012.02.085.

27. Shafigh, P.; Jumaat, M.Z.; Mahmud, H.B.; Alengaram, U.J. (2013) Oil Palm Shell Lightweight Concrete Containing High Volume Ground Granulated Blast Furnace Slag. Constr. Build. Mater. 40, 231-238. https://doi.org/10.1016/j. conbuildmat.2012.10.007.

28. Arora, A., Sant, G.; Neithalath, N. (2016) Ternary Blends Containing Slag and Interground/Blended Limestone: Hydration, Strength, and Pore Structure. Constr. Build. Mater. 102, 113-124. https://doi.org/10.1016/j. conbuildmat.2015.10.179.

29. Özbay, E.; Erdemir, M.; Durmuş, H.İ. (2016) Utilization and Efficiency of Ground Granulated Blast Furnace Slag on Concrete Properties - A Review. Constr. Build. Mater. 105, 423-434. https://doi.org/10.1016/j. conbuildmat.2015.12.153.

30. Siddique, R.; Kaur, D. (2012) Properties of Concrete Containing Ground Granulated Blast Furnace Slag (GGBFS) at Elevated Temperatures. J. Adv. Res. 3 [1], 45-51. https://doi.org/10.1016/j.jare.2011.03.004.
31. Siddique, R. (2014) Utilization (Recycling) of Iron and Steel Industry by-Product (GGBS) in Concrete: Strength and Durability Properties. J. Mater. Cycles Waste Manag. 16 [3], 460-467. https://doi.org/10.1007/ s10163-013-0206-x.

32. Zhang, W.; Ba, H. (2012) Effect of Ground Granulated Blast-Furnace Slag (GGBFS) and Silica Fume (SF) on Chloride Migration through Concrete Subjected to Repeated Loading. China Technol. Sci. 55 [11], 3102-3108. https://doi.org/10.1007/s11431-012-5027-y.

33. Güneyisi, E.; Gesoğlu, M. (2008) A Study on Durability Properties of High-Performance Concretes Incorporating High Replacement Levels of Slag. Mater. Struct. 41 [3], 479-493. https://doi.org/10.1617/s11527-007-9260-y.

34. Mo, K.H.; Alengaram, U.J.; Jumaat, M.Z. (2015) Utilization of Ground Granulated Blast Furnace Slag as Partial Cement Replacement in Lightweight Oil Palm Shell Concrete. Mater. Struct. 48 [8], 2545-2556. https://doi. org/10.1617/s11527-014-0336-1.

35. Ortega, J.M.; Pastor, J.L.; Albaladejo, A.; Sánchez, I.; Climent, M.A. (2014) Durability and Compressive Strength of Blast Furnace Slag-Based Cement Grout for Special Geotechnical Applications. Mater. Construcc. 64 [313], e003. https://doi.org/10.3989/mc.2014.04912.

36. Rodríguez, E.; Bernal, S.; Mejía de Gutiérrez, R.; Puertas, F. (2008) Hormigón Alternativo Basado En Escorias Activadas Alcalinamente. Mater. Construcc. 58 [291]. https://doi.org/10.3989/mc.2008.v58.i291.104.

37. Barin, D.S. (2008) Carbonatação e absorção capilar em concretos de cimento portland branco com altos teores de adição de escória de alto forno e ativador químico. Tesis de Mestre em Engenharia Civil. Universidade Federal de Santa Maria.

38. Costa, M.P.; Silva, M.G.; Pinheiros, S.M.M.; Souza, F.L.S.; Zandonade, E.; Coelho, M.A.M.; Morimoto, T. (2005) Concretos Com Altos Teores de Escória de Alto Forno: Avaliação Da Carbonatação e Da Difusão de Ions Cloreto. 47o Congresso Brasileiro Do Concreto - IBRACON, Recife.

39. Bernal, S.A.; San Nicolas, R.; Provis, J.L.; Mejía de Gutiérrez, R.; van Deventer, J.S.J. (2014) Natural Carbonation of Aged Alkali-Activated Slag Concretes. Mater. Struct. 47 [4], 693-707. https://doi.org/10.1617/ s11527-013-0089-2

40. Bernal, S.A. (2009) Carbonatación en concretos producidos a partir de sistemas binarios de una escoria siderúrgica y un metacaolin activados alcalinamente. Tesis Doctoral. Universidad del Valle, Cali, Colombia.

41. Bakharev, T.; Sanjayan, J.G.; Cheng, Y.B. (2003) Resistance of Alkali-Activated Slag Concrete to Acid Attack. Cem. Concr. Res. 33 [10], 1607-1611. https://doi.org/10.1016/ S0008-8846(03)00125-X.

42. Puertas, F.; Torres, T.J.; Varga, C. (2013) Procedimiento Para La Fabricación de Cementos Alcalinos a Partir de Residuos Vítreos Urbanos e Industriales. Patente ES2394979 A1. http://hdl.handle.net/10261/94567.

43. Bernal, S.A.; Mejía de Gutiérrez, R.; Provis, J.L. (2012) Engineering and Durability Properties of Concretes Based on Alkali-Activated Granulated Blast Furnace Slag/ Metakaolin Blends. Constr. Build. Mater. 33, 99-108. https://doi.org/10.1016/j.conbuildmat.2012.01.017.

44. Ferreira, M.B. (2013) Estudo Da Carbonatação Natural de Concretos Com Diferentes Adições Minerais Após 10 Anos de Exposição. Tesis de Mestre em Engenharia Civil. Universidade Federal de Goiás.

45. Ho, D.W.S.; Lewis, R.K. (1987) Carbonation of Concrete and Its Prediction. Cem. Concr. Res. 17 [3], 489-504. https://doi.org/10.1016/0008-8846(87)90012-3.

46. Mejía de Gutiérrez, R.; Rodríguez, C.; Rodríguez, E.; Torres, J.; Delvasto, S. (2009) Concreto Adicionado Con Metacaolín: Comportamiento a Carbonatación y Cloruros. Rev. Fac. Ing. Univ. Antioquia, 48, 55-64.

47. Castro, A.; Ferreira, R.; Lopes, A.M.; Cascudo, O.; Carasek, H. (2004) Relationship between Results of Accelerated and Natural Carbonation in Various Concretes. In: Vázquez, E., Hendriks, C.F. and Janssen, 
G.M.T., Eds., International RILEM Conference on the Use of Recycled Materials in Building and Structures, RILEM Publications SARL, Barcelona, 988-997.

48. Helene, P.R.D.L.; Castro-Borges, P. (2009) A Novel Method to Predict Concrete Carbonation. Concr. Cem. Investig. Des. 1 [1], 25-35.

49. Duffó, G.; Morris, W.; Raspini, I.; Saragovi, C. (2004) A Study of Steel Rebars Embedded in Concrete during 65 Years. Corros. Sci. 46 [9], 2143-2157. https://doi. org/10.1016/j.corsci.2004.01.006.

50. Uller, L.; Troconis de Rincon, O.; Alanis, I.; Helene, P.; Mejía de Gutiérrez, R.; O'Reilly, V.; Andrade, C.; Carpio, J.J.; Díaz, I.; Salta, M.; Rodríguez, G.; Romero de Carruyo, A.; Sagues, A. (1998) Manual de Inspección, Evaluación y Diagnostico de Corrosión En Estructuras de Hormigón Armado. 2da edición. CYTED.

51. Aperador, W.; Mejía de Gutiérrez, R.; Bastidas, D.M (2009) Steel Corrosion Behaviour in Carbonated AlkaliActivated Slag Concrete. Corros. Sci. 51 [9], 2027-2033. https://doi.org/10.1016/j.corsci.2009.05.033.

52. Aperador, W.C.; Ruiz, J.H.B.; Gómez, R. (2012) Corrosion of Reinforcing Bars Embedded in Alkali-Activated Slag Concrete Subjected to Chloride Attack. Mater. Res. 15 [1], 57-62. https://doi.org/10.1590/S1516-14392011005000096.
53. Bernal, S.A.; Provis, J.L.; Mejía de Gutiérrez, R.; van Deventer, J.S.J. (2015) Accelerated Carbonation Testing of Alkali-Activated Slag/Metakaolin Blended Concretes: Effect of Exposure Conditions. Mater. Struct. 48 [3], 653669. https://doi.org/10.1617/s11527-014-0289-4.

54. Alcaide, J.S.; Alcocel, E.G.; Puertas, F.; Lapuente, R.; Garcés, P. (2007) Comportamiento de Morteros de Escoria Activada Alcalinamente Con Adición de Fibras de Carbón. Mater. Construcc. 57 [288]. https://doi. org/10.3989/mc.2007.v57.i288.63.

55. Bernal, S.A. (2015) The Resistance of Alkali-Activated Cement-Based Binders to Carbonation. Handbook of Alkali-Activated Cements, Mortars and Concretes, Elsevier, 319-332. https://doi.org/10.1533/9781782422884.3.319.

56. Cadore, W. (2008) Estudo Da Carbonatação Da Camada de Cobrimento de Protótipos de Concreto Com Altos Teores de Adições Minerais e Cal Hidratada. Tesis de Mestre em Engenharia Civil. Universidade Federal de Santa Maria.

57. Bastidas, D.M.; Fernández-Jiménez, A.; Palomo, A.; González, J.A. (2008) A Study on the Passive State Stability of Steel Embedded in Activated Fly Ash Mortars. Corros. Sci. 50 [4], 1058-1065. https://doi.org/10.1016/j. corsci.2007.11.016. 